\title{
Solar modulation of flood frequency in central Europe during spring and summer on interannual to multi-centennial timescales
}

\author{
Markus Czymzik $^{1, \mathrm{a}}$, Raimund Muscheler ${ }^{2}$, and Achim Brauer ${ }^{1}$ \\ ${ }^{1}$ GFZ German Research Centre for Geosciences, Section 5.2 Climate Dynamics and Landscape Evolution, Potsdam, Germany \\ ${ }^{2}$ Department of Geology - Quaternary Sciences, Lund University, Lund, Sweden \\ anow at: Department of Geology - Quaternary Sciences, Lund University, Lund, Sweden
}

Correspondence to: Markus Czymzik (markus.czymzik@geol.lu.se)

Received: 22 September 2015 - Published in Clim. Past Discuss.: 13 October 2015

Revised: 3 February 2016 - Accepted: 7 March 2016 - Published: 1 April 2016

\begin{abstract}
Solar influences on climate variability are one of the most controversially discussed topics in climate research. We analyze solar forcing of flood frequency in central Europe during spring and summer on interannual to multi-centennial timescales, integrating daily discharge data of the River Ammer (southern Germany) back to AD 1926 ( solar cycles 16-23) and the 5500-year flood layer record from varved sediments of the downstream Ammersee. Flood frequency in the River Ammer discharge record is significantly correlated to changes in solar activity when the flood record lags the solar signal by $2-3$ years (2-year lag: $r=-0.375, p=0.01$; 3 -year lag: $r=-0.371, p=0.03)$. Flood layer frequency in the Ammersee sediment record depicts distinct multi-decadal variations and significant correlations to a total solar irradiance reconstruction $(r=-0.4, p<0.0001)$ and ${ }^{14} \mathrm{C}$ production rates $(r=0.37, p<0.0001)$, reflecting changes in solar activity. On all timescales, flood frequency is higher when solar activity is reduced. In addition, the configuration of atmospheric circulation associated with periods of increased River Ammer flood frequency broadly resembles that during intervals of reduced solar activity, as expected to be induced by the so-called solar top-down mechanism by model studies. Both atmospheric patterns are characterized by an increase in meridional airflow associated with enhanced atmospheric blocking over central Europe. Therefore, the significant correlations as well as similar atmospheric circulation patterns might provide empirical support for a solar influence on hydroclimate extremes in central Europe during spring and summer by the so-called solar top-down mechanism.
\end{abstract}

\section{Introduction}

Solar forcing of climate variability is one of the most controversially discussed topics in climate research. On the one hand, numerous empirical associations between the activity of the Sun and climate variables like temperature, precipitation, atmospheric circulation and frequency and intensity of hydrometeorological extremes indicate a solar influence on climate on regional scales (Adolphi et al., 2014; Bond et al., 2001; Fleitmann et al., 2003; Gray et al., 2010; Lockwood, 2012; Wirth et al., 2013). On the other hand, it is assumed that the measured variations in total solar irradiance (TSI) of about $1.4 \mathrm{~W} \mathrm{~m}^{-2}$ are too small to substantially modify climate unless they can induce amplifying feedbacks in the climate system (IPCC, 2013). One amplifying feedback proposed by model studies is the so-called solar top-down mechanism (Gray et al., 2010; Haigh, 1996; Ineson et al., 2011; Lockwood, 2012). Larger changes in solar UV emissions influence stratospheric ozone concentration, heating and circulation and, consequently, strength and stability of the polar vortex. These disturbances are expected to communicate downwards to the troposphere via a chain of processes that is still under investigation to modify position and strength of the midlatitude storm tracks mainly over the North Atlantic and Europe (Gray et al., 2010; Haigh, 1996; Ineson et al., 2011; Lockwood, 2012). Under further consideration are the effects of energetic particles from the Sun and galactic cosmic rays on cloud cover and precipitation. However, their climate impact is not well understood 
(Gray et al., 2010; Lockwood, 2012; Svensmark and FriisChristensen, 1997).

In addition to model studies, a way to investigate potential solar-climate linkages and their underlying mechanisms on short and long timescales and with high temporal precision is to integrate short instrumental records and long paleoclimate proxy time series reflecting the same type of data (Kämpf et al., 2014). Flood layers in the varved Ammersee sediment record form after major River Ammer floods, transporting eroded detrital catchment material into the lake (Czymzik et al., 2010, 2013). Flood layer frequency has been shown to follow changes in solar activity during the last 450 years (Czymzik et al., 2010). In addition, millennialscale shifts in flood intensity at the Ammersee are likely related to a successive reduction in Northern Hemisphere orbital summer forcing and multi-millennial solar activity variations (Czymzik et al., 2013). A major aim of this study is to investigate the instrumental River Ammer discharge record from Gauge Weilheim reaching back to AD 1926 for highfrequency solar signals (Fig. 1). The analyses focus on May to August (MJJA), the flood season in the Ammer region today (Czymzik et al., 2010). In order to provide information on River Ammer flood activity in the more distant past, we perform novel analyses on the previously published 5500year flood layer time series from Ammersee sediment core AS10 $0_{\text {prox }}$ (Fig. 1). The proximity between Gauge Weilheim, recording discharge from 607 of the $709 \mathrm{~km}^{2}$ Ammer catchment, and the downstream lake ensures comparability of the flood signals in both records (Fig. 1).

\section{Material and methods}

\subsection{Study site}

The River Ammer has a length of $84 \mathrm{~km}$ and is located in the Bavarian Alpine Foreland (southern Germany) (Mangelsdorf and Zelinka, 1973) (Fig. 1). Its catchment is well suited for the investigation of flood occurrences. High water tables of the moorlands in the vicinity to the Ammersee and low waterholding capacities of the Alpine soils favor the translation of precipitation extremes into floods by surface discharge. The rather small catchment $\left(709 \mathrm{~km}^{2}\right)$ and steep slopes of the Alpine foothills produce short but intense flood peaks (Ludwig et al., 2003).

The Ammersee $\left(48^{\circ} 00^{\prime} \mathrm{N}, 11^{\circ} 07^{\prime} \mathrm{E}, 533 \mathrm{~m}\right.$ a.s.l.) has a surface area of $47 \mathrm{~km}^{2}$ and a maximum water depth of $81 \mathrm{~m}$ (Alefs and Müller, 1999). Late moraine, flysch and molasse formations in the Ammer catchment provide abundant easy erodible detrital material for downstream transport into the lake during a flood. The gully-shaped lake basin provides a well-defined deposition center for these detrital fluxes as distinct "flood layers" (Czymzik et al., 2010). Varved sediments allow dating these flood layers to the season by varve counting and the position within an annual lacustrine sedimentation cycle (Czymzik et al., 2010).
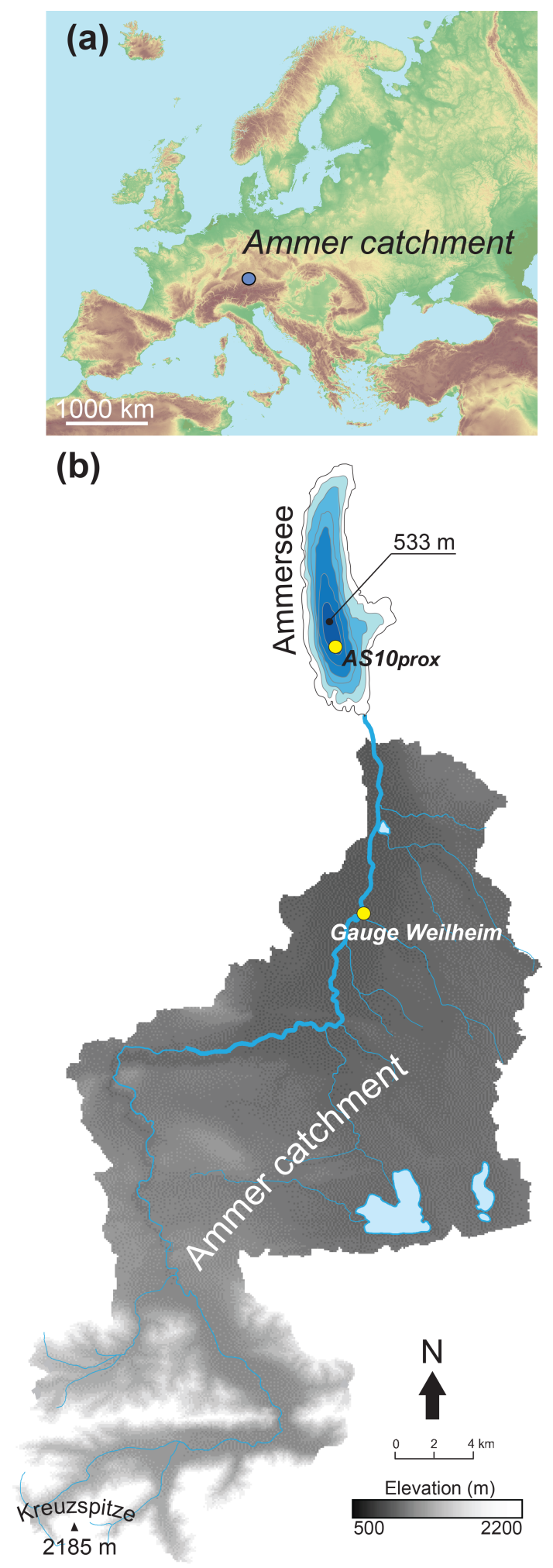

Figure 1. (a) Geographical position of the Ammer catchment. (b) Hydrological map of the Ammer catchment (modified after Ludwig et al., 2003) and bathymetric map of the Ammersee with positions of Gauge Weilheim and sediment core AS10 prox. 
The hydroclimate in the Ammer region, today, is characterized by varying influences of midlatitude westerly weather regimes transporting moisture from the North Atlantic and Mediterranean into Europe and continental highpressure cells causing atmospheric blocking (Petrow and Merz, 2009). Mean annual precipitation in the Ammer catchment is $\sim 1200$ mm year $^{-1}$.

\subsection{River Ammer discharge data}

Daily River Ammer discharge data provided by the Bavarian Environmental Agency were recorded at Gauge Weilheim (550 ma.s.1.), located about $10 \mathrm{~km}$ upstream of the Ammersee (Fig. 1). The discharge data cover the period AD 1926-2010, and the analyses focus on May-August. To better link the River Ammer discharge record to floods as represented by the Ammersee flood layer time series, flood frequency indices were calculated by counting days in MJJA with daily discharges between 31 and $42 \mathrm{~m}^{3} \mathrm{~s}^{-1}$ (discharges between the 90th and 95th percentile) and above $42 \mathrm{~m}^{3} \mathrm{~s}^{-1}$ (discharges above the 95th percentile). Two threshold levels were chosen to extract more complete time series of major River Ammer floods varying substantially in length and magnitude. A MJJA River Ammer flood frequency composite was calculated by averaging the indices related to both discharge thresholds. To reduce noise, the River Ammer flood frequency composite was filtered with a 5-year running mean.

\subsection{Ammersee flood layer record}

Detrital layers in the varved Ammersee sediment core AS10 prox have been previously interpreted to reflect major River Ammer floods during spring and summer by their (1) sediment microfacies indicating deposition after major surface discharge events, (2) increases in Ti evincing the terrestrial origin of the material, (3) proximal-distal deposition pattern pointing towards the River Ammer as the introductory source, (4) position within an annual sediment deposition cycle and (5) calibration against instrumental River Ammer discharge data (Czymzik et al., 2010, 2013). A 30-year moving window was applied to the flood layer time series to emphasize multi-decadal variability.

\subsection{Cross-wavelet analysis}

Cross-wavelet analysis reveals regions in two time series with common high spectral power and provides information on the phase relationship (Grinsted et al., 2004). The wavelets were produced using a Morlet mother wavelet. Significance levels were calculated against a red noise spectrum (Grinsted et al., 2004). Before the analyses, all data sets were standardized (zero mean, standard deviation).

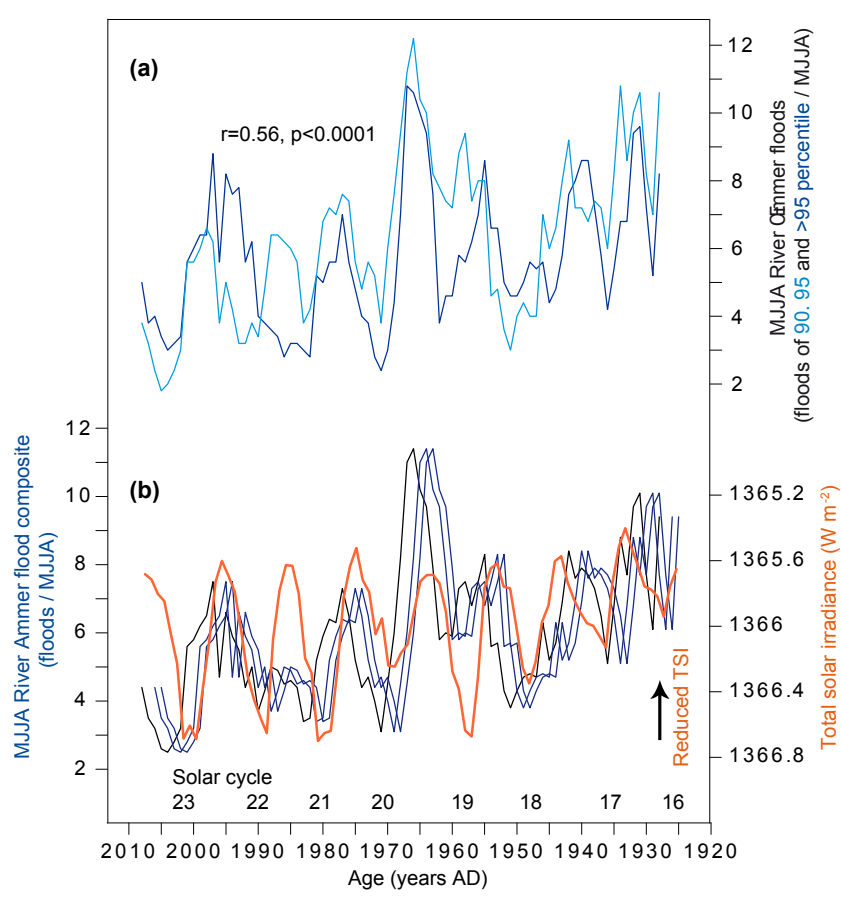

Figure 2. River Ammer flood frequency in the discharge record and solar activity. (a) Frequency of River Ammer floods during MJJA with discharges between the 90th and 95th percentile as well as above the 95th percentile. (b) River Ammer flood frequency composite (see Sect. 2) and total solar irradiance (TSI) during solar cycles 16-23 (Lean, 2000). The black line indicates the original River Ammer flood frequency composite. The blue lines represent the River Ammer flood frequency composite shifted for 2 and 3 years into the past, revealing significant correlations with TSI (see Fig. 4). The River Ammer flood records were filtered using a 5-year running mean. Correlations were calculated using a random-phase test (Ebisuzaki, 1997).

\subsection{Random-phase significance test}

Correlation coefficients and significance levels were calculated using a non-parametric random-phase test (Ebisuzaki, 1997). This test is designed for serially correlated time series and, thus, takes into account the effects of smoothing and detrending. It is based on the creation of (here 10000 ) random time series that have an identical frequency spectrum to the original data series A but randomly differ in the phase of each frequency. To test the significance of the correlation between $\mathrm{A}$ and $\mathrm{B}, \mathrm{A}$ is then replaced with these random surrogates, and the probability distribution of the correlations that may occur by chance is calculated (Ebisuzaki, 1997).

\section{Results}

\subsection{River Ammer flood frequency back to AD 1926}

The MJJA River Ammer flood frequency indices for discharges between the 90th and 95th percentile and above the 


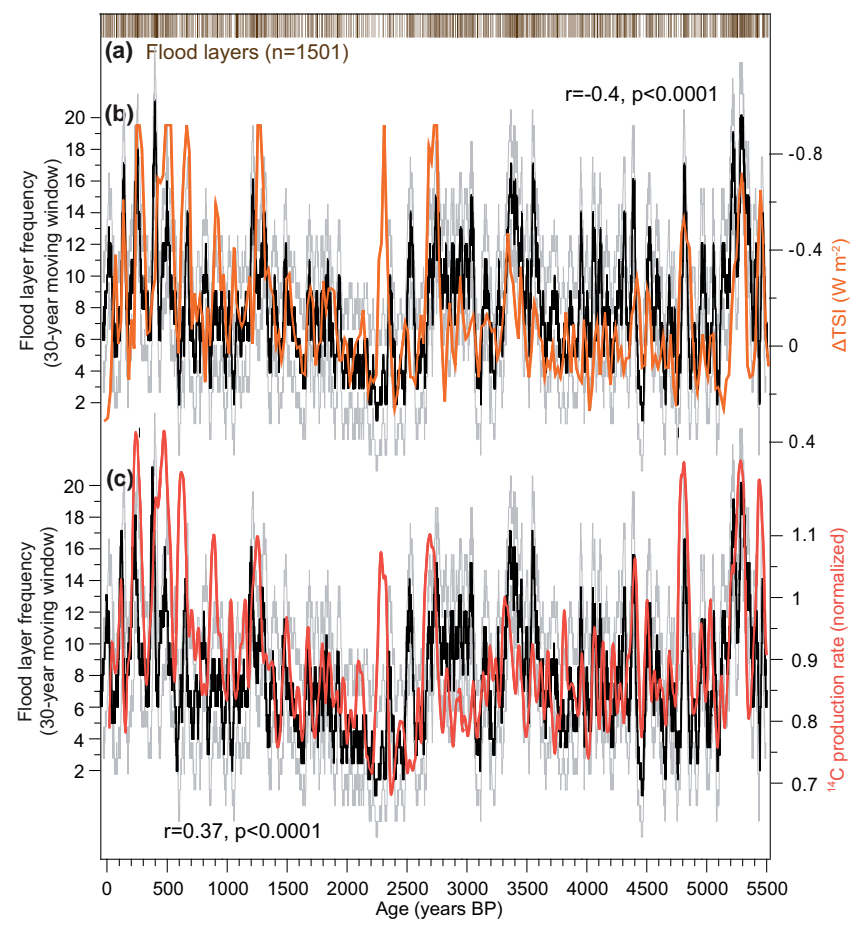

Figure 3. Flood layer frequency and solar activity. (a) Flood layers in Ammersee sediment core AS10 prox. (b) Flood layer frequency (30-year moving window) and reconstructed total solar irradiance (difference to the value of the Davos Physical Meteorological Observatory (PMOD) composite during the solar cycle minimum in AD 1986) (Steinhilber et al., 2012). (c) Flood layer frequency (30-year moving window) and ${ }^{14} \mathrm{C}$ production rate (Muscheler et al., 2007). Gray lines indicate the standard deviation of the smoothed flood layer record. Correlations were calculated using a random-phase test (Ebisuzaki, 1997).

95th percentile are significantly correlated from AD 1926 to $2010(r=0.56, p<0.0001)$, suggesting the reflection of a common hydrological signal (Fig. 2). As already depicted by the two single flood indices, the MJJA River Ammer flood frequency composite exhibits distinct decadal-scale oscillatory behavior and a trend towards lower flood frequencies during the more recent years (Fig. 2).

\subsection{Flood layer frequency over the last 5500 years}

Flood layers in Ammersee sediment core AS10 prox during the last 5500 years reveal distinct decadal-scale frequency fluctuations, ranging from 2 layers every 30 years to 20 layers every 30 years (Fig. 3). Mean flood layer recurrence time is 3.7 years.

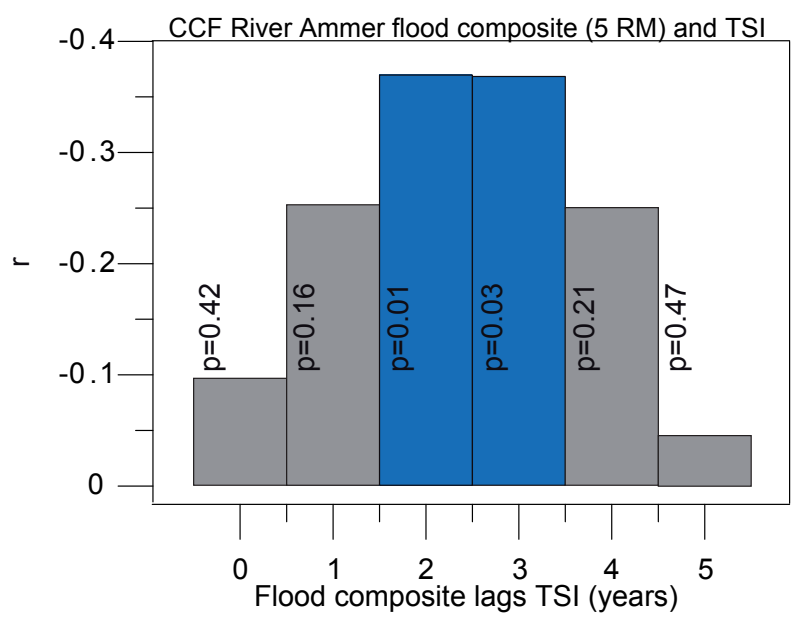

Figure 4. Cross correlation between the MJJA River Ammer flood frequency composite from the discharge record and total solar irradiance (TSI) (Lean, 2000) indicating significant negative correlations when the River Ammer flood frequency composite lags TSI by 2 to 3 years. Prior to the analysis, the River Ammer flood frequency composite was filtered with a 5-year running mean. Correlations were calculated using a random-phase test (Ebisuzaki, 1997).

\section{Discussion}

\subsection{River Ammer floods and solar activity in the instrumental period}

Comparing the MJJA River Ammer flood frequency composite from the discharge record to an annually resolved TSI reconstruction (Lean, 2000) allows examining solar-flood correspondences at very high temporal resolution based on fixed chronologies. Interestingly, interannual variability in the River Ammer flood frequency composite follows changes in TSI during solar cycles 16-23 (Fig. 2). Both records are broadly anti-phased (Fig. 2). Discrepancies between the MJJA River Ammer flood frequency composite and TSI might be caused by internal climate variability and local climate anomalies. Furthermore, particularly the weak increase in the River Ammer flood frequency composite during the TSI minimum between solar cycles 21 and 22 is likely due to the static nature of the chosen discharge thresholds. Nevertheless, even though no increase in flood frequency is visible during that time for floods with discharges above the 95th percentile, an increase in the frequency of floods with discharges between the 90th and 95th percentile is recorded (Fig. 2). A trend towards lower River Ammer flood frequencies during the more recent years is paralleled by a trend towards higher solar activity (Fig. 2).

Cross correlation indicates significant negative correlations when the River Ammer flood frequency composite lags TSI by 2-3 years (2-year lag: $r=-0.375, p=0.01$; 3 -year lag: $r=-0.371, p=0.03$ ) (Fig. 4). A temporal lag of flood responses to changes in solar activity of a few years might be 


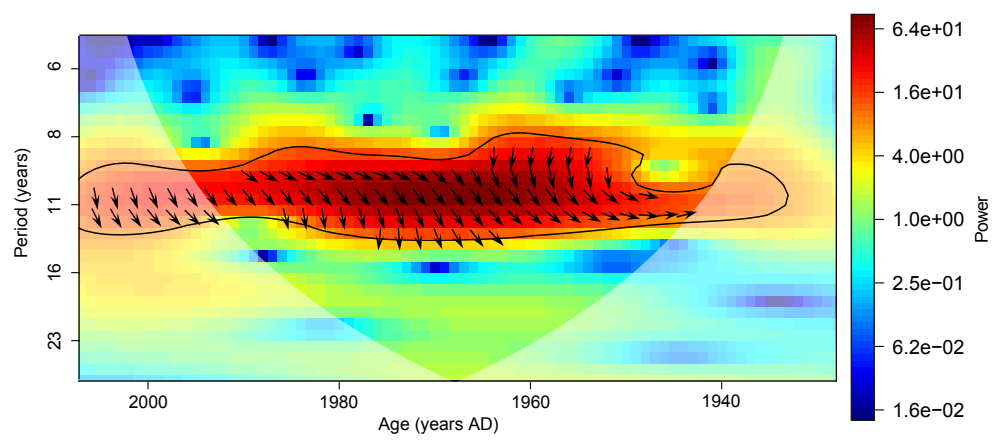

Figure 5. Cross-wavelet analysis of MJJA River Ammer flood frequency composite and total solar irradiance (TSI) (Lean, 2000) indicating significant common spectral power (exceeding the $90 \%$ significance level against a red noise spectrum) around 11 years. Arrows pointing down indicate that TSI leads the River Ammer flood frequency composite. Before the analysis the River Ammer flood frequency composite was filtered with a 5-year running mean. Shaded areas indicate the cone of influence where wavelet analysis is affected by edge effects.

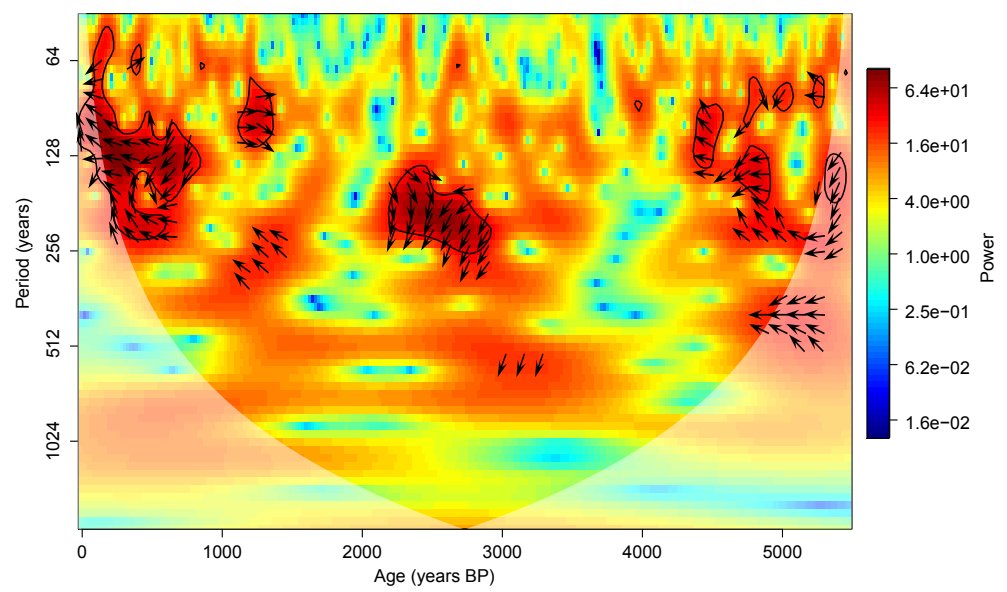

Figure 6. Cross-wavelet analysis of the Ammersee flood layer (30-year running window) and reconstructed total solar irradiance records (Steinhilber et al., 2012). Contoured areas exceed the $90 \%$ significance level against a red noise spectrum. Arrows pointing to the left indicate that the time series are anti-phased. Before the analysis, the Ammersee flood layer record was resampled to the resolution of the TSI time series (approximately one data point in 20 years). Shaded areas indicate the cone of influence where wavelet analysis is affected by edge effects.

explained by a modelled ocean-atmosphere feedback (Scaife et al., 2013): solar-induced variations in the North Atlantic heat budget are expected to delay the atmospheric response to solar activity variations up to a few years through the later release of previously accumulated energy to the air (Scaife et al., 2013). Cross-wavelet analysis of the River Ammer flood frequency composite and TSI indicates significant common spectral power around 9-12 years similar to the solar Schwabe cycle and a negative phase relationship (Fig. 5).

\subsection{Flood layer frequency and solar activity during the last 5500 years}

Comparing the 5500-year flood layer frequency record to solar activity indicators from cosmogenic radionuclides enables investigating solar-climate linkages on long timescales. Comparable to the last 450 years (Czymzik et al., 2010), the 5500-year flood layer frequency time series $(n=1501$, filtered with a 30 -year moving window) depicts distinct multi-decadal variations and significant correlations with a total solar irradiance reconstruction (Steinhilber et al., 2012) $(r=-0.4, p<0.0001)$ and the reconstructed ${ }^{14} \mathrm{C}$ production rate, a proxy record of changes in solar activity, especially on sub-millennial timescales (Muscheler et al., 2007; Snowball and Muscheler, 2007) $(r=0.37$, $p<0.0001$ ) (Fig. 3). The atmospheric production of ${ }^{14} \mathrm{C}$ is influenced by the activity of the Sun. A more active Sun enhances heliomagnetic shielding and thereby reduces the flux of galactic cosmic rays to Earth's upper atmosphere, forming ${ }^{14} \mathrm{C}$ by the interaction with $\mathrm{N}$ and $\mathrm{O}$ (Lal and Peters, 1967). Consequently, more ${ }^{14} \mathrm{C}$ is produced when solar activity is reduced. In addition to the multi-decadal variations, cross-wavelet analysis of the flood layer frequency and TSI (Steinhilber et al., 2012) records yields significant common 
low-frequency oscillations around 90 and 210 years, likely reflecting the solar Gleissberg and Suess cycles, particularly during periods of grand solar minima around 250, 2800 and 5300 varve years BP (Fig. 6). Furthermore, the analysis reveals a dominantly anti-phased behavior between flood layer frequency and TSI (Fig. 6).

\subsection{Mechanism for a solar influence on flood frequency}

Significant negative correlations between solar activity and River Ammer flood frequency on interannual to multicentennial timescales suggest a solar modulation of the frequency of hydrometeorological extremes in the Ammer region (Figs. 2, 3, 4, 5, 6). Further empirical associations between flood frequency and solar activity in records from the Alpine region and central Spain (Moreno et al., 2008; Peña et al., 2015; Vaquero, 2004; Wirth et al., 2013) as well as the agreement with a flood reconstruction from multiple large European rivers of the last 500 years (Glaser et al., 2010) suggest a larger spatial relevance (central Europe) of the flood signal from the Ammer catchment.

One proposed solar-climate linkage is the so-called solar top-down mechanism, expected to modulate the characteristics of the midlatitude storm tracks over the North Atlantic and Europe by model studies (Haigh, 1996; Ineson et al., 2011; Lockwood, 2012). During periods of reduced solar activity, the storm tracks are projected to be on a more southward trajectory. Reduced zonal pressure gradients favor atmospheric blocking and meridional airflow (see the Introduction for details) (Adolphi et al., 2014; Haigh, 1996; Ineson et al., 2011; Lockwood, 2012; Wirth et al., 2013). A similar synoptic-scale configuration of atmospheric circulation is associated with periods of higher River Ammer flood frequency (Rimbu et al., 2016). Periods of higher flood frequency are characterized by a pronounced trough over western Europe intercalated between two ridges south of Greenland and north of the Caspian Sea (Rimbu et al., 2016). Meridional moisture transport mainly from the North Atlantic towards central Europe along the frontal zones of these air-pressure fields increases the flood risk in the Ammer region (Rimbu et al., 2016). These similar atmospheric circulation patterns might suggest that the observed solar activity-flood frequency linkage is related to the so-called solar top-down mechanism. However, we cannot rule out further effects of changes in TSI and/or galactic cosmic rays on River Ammer flood occurrences. The inconsistency that the solar top-down mechanism is active mainly during winter and early spring while River Ammer floods occur during late spring and summer might be reconciled by the effects of cryospheric processes. Ice cover in the Barents Sea and snow in Siberia are expected to transfer the dominant potentially solar-induced winter climate signal into summer (Ogi et al., 2003).

\section{Conclusions}

Integrating daily River Ammer discharge data back to AD 1926 and a 5500-year flood layer record from varved sediments of the downstream Ammersee allowed identifying changes in flood frequency in central Europe during spring and summer and their triggering mechanism on interannual to multi-centennial timescales. Flood frequency in both records is significantly correlated to changes in solar activity from the solar Schwabe cycle to multi-centennial oscillations. These significant correlations suggest a solar influence on the frequency of hydroclimate extremes in central Europe. Similar configurations of atmospheric circulation during periods of increased flood frequency and reduced solar activity, as expected to be caused by the so-called solar top-down mechanism by model studies, might indicate that the observed solar activity-flood frequency linkage is related to this feedback. The unexpected direct response of variations in River Ammer flood frequency to changes in solar activity might suggest that the solar top-down mechanism is of particular relevance for hydroclimate extremes. Future climate model studies might help to provide a better mechanistic understanding and test our hypotheses on the linkage between solar activity and flood frequency in central Europe during spring and summer.

\section{Data availability}

Ammersee flood layer data files are archived in the PANGAEA data library (http://doi.pangaea.de/10.1594/ PANGAEA.803369).

Acknowledgements. This study is a contribution to the Helmholtz Association (HGF) climate initiative REKLIM Topic 8 "Rapid climate change derived from proxy data" and was carried out using TERENO infrastructure financed by the HGF. We thank Florian Adolphi for providing the program for the random-phase test.

The article processing charges for this open-access publication were covered by a Research

Centre of the Helmholtz Association.

Edited by: D. Fleitmann

\section{References}

Adolphi, F., Muscheler, R., Svensson, A., Aldahan, A., Possnert, G., Beer, J., Sjolte, J., Björck, S., Matthes, K., and Thiéblemont, R.: Persistent link between solar activity and Greenland climate during the Last Glacial Maximum, Nat. Geosci., 7, 662-666, 2014.

Alefs, J. and Müller, J.: Differences in the eutrophication dynamics of Ammersee and Starnberger See (Southern Germany), reflected by the diatom succession in varve-dated sediments, J. Paleolimnol., 21, 395-407, 1999. 
Bond, G., Kromer, B., Beer, J., Muscheler, R., Evans, M. N., Showers, W., Hoffmann, S., Lotti-Bond, R., Hajdas, I., and Bonani, G.: Persistent solar influence on North Atlantic climate during the Holocene, Science, 294, 2130-2136, 2001.

Czymzik, M., Brauer, A., Dulski, P., Plessen, B., Naumann, R., von Grafenstein, U., and Scheffler, R.: Occurence and thickness of flood layers in varved sediments of Lake Ammersee, doi:10.1594/PANGAEA.803369, 2012.

Czymzik, M., Dulski, P., Plessen, B., von Grafenstein, U., Naumann, R., and Brauer, A.: A 450 year record of spring-summer flood layers in annually laminated sediments from Lake Ammersee (southern Germany), Water Resour. Res., 46, W11528, doi:10.1029/2009WR008360, 2010.

Czymzik, M., Brauer, A., Dulski, P., Plessen, B., Naumann, R., von Grafenstein, U., and Scheffler, R.: Orbital and solar forcing of shifts in Mid- to Late Holocene flood intensity from varved sediments of pre-alpine Lake Ammersee (southern Germany), Quaternary Sci. Rev., 61, 96-110, 2013.

Ebisuzaki, W.: A method to estimate the statistical significance of a correlation when the data are serially correlated, J. Climate, 10, 2147-2153, 1997.

Fleitmann, D., Burns, S. J., Mudelsee, M., Neff, U., Kramers, J., Mangini, A., and Matter, A.: Holocene forcing of the Indian monsoon recorded in a stalagmite from southern Oman, Science, 300, 1737-1739, doi:10.1126/science.1083130, 2003.

Glaser, R., Riemann, D., Schönbein, J., Barriendos, M., Brázdil, R., Bertolin, C., Camuffo, D., Deutsch, M., Dobrovolný, P., Engelen, A., Enzi, S., Halíčková, M., Koenig, S. J., Kotyza, O., Limanówka, D., Macková, J., Sghedoni, M., Martin, B., and Himmelsbach, I.: The variability of European floods since AD 1500, Climatic Change, 101, 235-256, 2010.

Gray, L. J., Beer, J., Geller, M., Haigh, J. D., Lockwood, M., Matthes, K., Cubasch, U., Fleitmann, D., Harrison, G., Hood, L., Luterbacher, J., Meehl, G. A., Shindell, D., van Geel, B., and White, W.: Solar influences on climate, Rev. Geophys., 48, RG4001, doi:10.1029/2009RG000282, 2010.

Grinsted, A., Moore, J. C., and Jevrejeva, S.: Application of the cross wavelet transform and wavelet coherence to geophysical time series, Nonlin. Processes Geophys., 11, 561-566, doi:10.5194/npg-11-561-2004, 2004.

Haigh, J. D.: The impact of solar variability on climate, Science, 272, 981-984, 1996.

Ineson, S., Scaife, A. A., Knight, J. R., Manners, J. C., Dunstone, N. J., Gray, L. J., and Haigh, J. D.: Solar forcing of winter climate variability in the Northern Hemisphere, Nat. Geosci., 4, 753-757, 2011.

IPCC: Climate Change 2013: The Physical Science Basis. Contribution of Working Group I to the Fifth Assessment Report of the Intergovernmental Panel on Climate Change, edited by: Stocker, T. F., Qin, D., Plattner, G. K., Tignor, M., Allen, S. K., Boschung, J., Nauels, A., Xia, Y., Bex, V., and Midgley, P. M., Cambridge University Press, Cambridge, United Kingdom and New York, NY, USA, 1535 pp., 2013

Kämpf, L., Brauer, A., Swierczynski, T., Czymzik, M., Müller, P., and Dulski, P.: Processes of flood-triggered detrital layer deposition in the varved Lake Mondsee sediment record revealed by a dual calibration approach, J. Quaternary Sci., 29, 475-486, 2014.
Lal, D. and Peters, B.: Cosmic ray produced radioactivity on the Earth, in: Encyclopedia of Physics, edited by: Sitte, K., Springer, Berlin Heidelberg, 551-612, 1967.

Lean, J.: Evolution of the Sun's spectral irradiance since the Maunder Minimum, Geophys. Res. Lett., 27, 2425-2428, 2000.

Lockwood, M.: Solar influence on global and regional vlimates, Surv. Geophys., 33, 503-534, 2012.

Ludwig, R., Taschner, S., and Mauser, W.: Modelling floods in the Ammer catchment: limitations and challenges with a coupled meteo-hydrological model approach, Hydrol. Earth Syst. Sci., 7 , 833-847, doi:10.5194/hess-7-833-2003, 2003.

Mangelsdorf, J. and Zelinka, K.: Zur Hydrochemie der Ammer (Oberbayern) und ihrer Zuflüsse, Wasserwirtschaft, 63, 1-5, 1973.

Moreno, A., Valero-Garcés, B. L., González-Sampériz, P., and Rico, M.: Flood response to rainfall variability during the last 2000 years inferred from the Taravilla Lake record (Central Iberian Range, Spain), J. Paleolimnol., 40, 943-961, 2008.

Muscheler, R., Joos, F., Beer, J., Müller, S. A., Vonmoos, M., and Snowball, I.: Solar activity during the last $1000 \mathrm{yr}$ inferred from radionuclide records, Quaternary Sci. Rev., 26, 82-97, 2007.

Ogi, M., Tachibana, Y., and Yamazaki, K.: Impact of the wintertime North Atlantic Oscillation (NAO) on the summertime atmospheric circulation, Geophys. Res. Lett., 30, 1704, doi:10.1029/2003GL017280, 2003.

Peña, J. C., Schulte, L., Badoux, A., Barriendos, M., and BarreraEscoda, A.: Influence of solar forcing, climate variability and modes of low-frequency atmospheric variability on summer floods in Switzerland, Hydrol. Earth Syst. Sci., 19, 3807-3827, doi:10.5194/hess-19-3807-2015, 2015.

Petrow, T. and Merz, B.: Trends in flood magnitude, frequency and seasonality in Germany in the period 1951-2002, J. Hydrol., 371, 129-141, 2009.

Rimbu, N., Czymzik, M., Ionita, M., Lohmann, G., and Brauer, A.: Atmospheric circulation patterns associated with the variability of River Ammer floods: evidence from observed and proxy data, Clim. Past, 12, 377-385, doi:10.5194/cp-12-377-2016, 2016.

Scaife, A. A., Ineson, S., Knight, J. R., Gray, L., Kodera, K., and Smith, D. M.: A mechanism for lagged North Atlantic climate response to solar variability, Geophys. Res. Lett., 40, 434-439, 2013.

Snowball, I. and Muscheler, R.: Palaeomagnetic intensity data: an Achilles heel of solar activity reconstructions, The Holocene, 17, 851-859, 2007.

Steinhilber, F., Abreu, J. A., Beer, J., Brunner, I., Christl, M., Fischer, H., Heikkilä, U., Kubik, P. W., Mann, M., McCracken, K. G., Miller, H., Miyahara, H., Oerter, H., and Wilhelms, F.: 9400 years of cosmic radiation and solar activity from ice cores and tree rings, P. Natl. Acad. Sci. USA, 109, 5967-5971, 2012.

Svensmark, H. and Friis-Christensen, E.: Variation of cosmic ray flux and global cloud coverage-a link in solar-climate relationships, J. Atmos. Sol.-Terr. Phys., 59, 1225-1232, 1997.

Vaquero, J. M.: Solar signal in the number of floods recorded for the Tagus river basin over the last millennium, Climatic Change, 66, 23-26, 2004.

Wirth, S. B., Glur, L., Gilli, A., and Anselmetti, F. S.: Holocene flood frequency across the Central Alps - solar forcing and evidence for variations in North Atlantic atmospheric circulation, Quaternary Sci. Rev., 80, 112-128, 2013. 